\title{
TGFBR1 wt Allele
}

National Cancer Institute

\section{Source}

National Cancer Institute. T GFBR1 wt Allele. NCI Thesaurus. Code C51730.

Human TGFBR1 wild-type allele is located within $9 q 22$ and is approximately $45 \mathrm{~kb}$ in length. This allele, which encodes TGF-beta receptor type-1 protein, is involved in TGFbeta signal transduction. Mutations in this gene have been associated with Loeys-Dietz aortic aneurysm syndrome. 